\title{
Plant diversity of tree and shrub strata of agroforestry homegardens in an agro-extractive settlement, Monte Alegre, Pará
}

\author{
Diversidade de plantas dos estratos arbóreos e arbustivos de quintais \\ agroflorestais em um Assentamento Agroextrativista, \\ Monte Alegre, Pará
}

\author{
Deiwisson Willam da Silva Santos' ${ }^{(\mathbb{D}}$, Thiago Almeida Vieira"I(I) \\ ' Universidade do Estado de Santa Catarina, Florianópolis, SC, Brasil \\ "Universidade Federal do Oeste do Pará, Santarém, PA, Brasil
}

\begin{abstract}
This study aimed to evaluate the floristic composition of 37 agroforestry homegardes of the community of São Diogo, located $40 \mathrm{~km}$ from the municipality of Monte Alegre, Pará. In order to reach these homegardens, the "snowball" technique was used. In the manager settlers' house, the data collection was done through tour-guided. Informations were collected about: plant species cultivated in tree and shrub strata, size and age of each system, and management practices. The Shannon index was used to assess the diversity of homegardens. There were 32 species belonging to 26 genera, divided into 18 botanical families, all of them fruit trees, $85.7 \%$ of which were used exclusively for self-consumption. The most frequent species were Cocos nucifera, Euterpe oleracea, Citrus limon and Mangifera indica. The homegardens presented on average 12 years of age, with average size 1,973 $\mathrm{m}^{2}$. It was highlighted the greater participation of women in the management decisions and activities of these systems. Homegardens are an important for food security and income sources for managers.
\end{abstract}

Key words: Agroforestry systems; Agroecosystems; Floristic composition

\section{RESUMO}

Este trabalho objetivou avaliar a composição florística de 37 quintais agroflorestais na comunidade de São Diogo, localizada a $40 \mathrm{~km}$ do município de Monte Alegre, Pará. Para se chegar a estes quintais, recorreu-se a técnica "bola de neve". Na casa do assentado manejador, a coleta de dados foi feita por meio de turnê-guiada. Levantaram-se informações sobre: espécies vegetais cultivadas nos estratos arbóreos e arbustivos, tamanho e idade dos sistemas, e práticas de manejo. O índice de Shannon foi utilizado para avaliação da diversidade dos quintais. Foram encontradas 32 espécies pertencentes a 26 gêneros, divididos em 18 famílias botânicas, todas frutíferas, sendo que 85,7\% delas utilizadas 
exclusivamente para autoconsumo. As espécies mais frequentes foram Cocos nucifera, Euterpe oleracea, Citrus limon e Mangifera indica. Os quintais apresentaram em média 12 anos de idade, com tamanho médio $1.973 \mathrm{~m}^{2}$. Os quintais se constituem como um importante sistema na segurança alimentar e fonte de renda dos manejadores.

Palavras-chave: Sistemas agroflorestais; Agroecossistemas; Composição florística

\section{INTRODUCTION}

The agroforestry systems (AFS) are land-use systems primarily managed by traditional populations, creating a source of income and providing several agroecosystem services (MICCOLIS et al., 2016; PINTO et al., 2020). These systems provide the cultivation of exotic and native plants, fruit and timber trees, etc., and its production can be used for household consumption and/or for commercialization (DAMACENO; LOBATO, 2019; RAYOL; MIRANDA, 2019), in addition to providing food and medicinal plants (DAS; DAS, 2020; GEORGE; CHRISTOPHER, 2020; MACENA, VILA, 2020; ABREU; SILVA; OLIVEIRA, 2017). These uses can make economic development and environmental conservation compatible.

In addition, the implementation and management of AFS provide great benefits in soil conservation, such as reducing water loss and improving soil quality, thereby enhancing the environmental quality of the area (ROMUALDO et al., 2019). These systems can also improve the microclimate of the area by providing shading and environmental comfort (PEREIRA; FIGUEIREDO NETO, 2015).

Among the various configurations of agroforestry systems, homegardens are characterized by being traditionally managed (GEORGE; CHRISTOPHER, 2020) and located near the houses of those who implemented and or/ manage them. These areas constitute the main source of subsistence agriculture for thousands of families in the Amazon region, who grow a wide variety of species for selfconsumption or commercialization, thus supplying food (GARCIA; VIEIRA; 
OLIVEIRA, 2017; RAYOL; MIRANDA, 2019) and improving the quality of life for the population (VIEIRA; ROSA; SANTOS, 2015).

The homegardens are probably one of the oldest forms of land-use management, consisting of an agricultural unit for traditional land use with management techniques that are passed down between generations (MIDMORE, 2015). Despite the benefits of food production and security of homegardens, little attention has been paid to these agroecosystems (RAYOL; MIRANDA, 2019).

The study of the floristic composition of homegardens allows for better understanding of the plant diversity conservation, including underutilized, wild, and rare species that are eroded because of adjacent land use systems (DAS; DAS, 2020).

Considering the importance of agroforestry homegardens for creating environmental and economic benefits, this work aimed to characterize the floristic composition of homegardens in an agro-extractive settlement located in the city of Monte Alegre, Pará, Brazil.

\section{MATERIAL AND METHODS}

The agro-extractive settlement project of São Diogo has settled 220 families since its establishment in 2006. Because the settlement is located near the Gurupatuba river, its economy is mainly driven by fishery. However, agriculture also contributes as a source of income for some of the households.

The present study evaluated the floristic composition of 37 agroforestry homegardens at the Agro-extractive Settlement Project of São Diogo, located 40

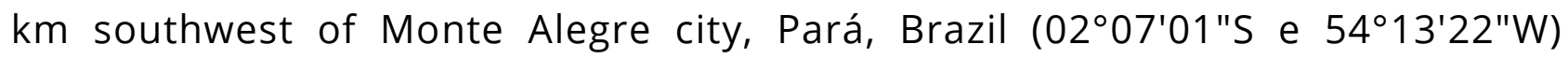
(Figure 1). The settlement is accessed via the PA-254 state highway, which connects the city of Santarém to other locations in the State of Pará. 
Figure 1 - Location of the study area, the rural community of São Diogo, Monte Alegre, Pará, Brazil

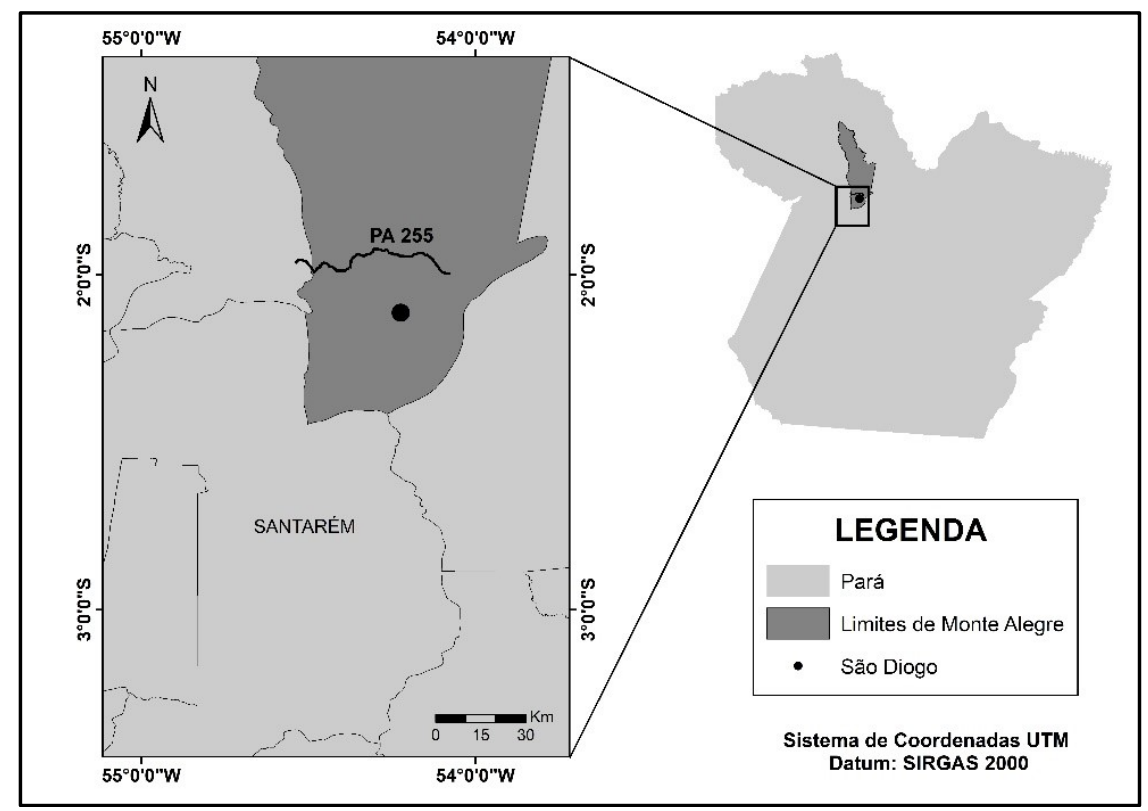

Source: Authors

The study was carried out in 37 homegardens, which were selected based on its apparent (visual) floristic diversity, including those of the community leaders. The community leader suggested the first household to be interviewed. Thereafter, the snowball technique was used (PINTO, 2012), where the first research participant introduces other potential participants for the study and considers the previously mentioned inclusion criterion.

According to Vinuto (2014), the snowball technique is a nonprobability sampling technique that is useful for studying certain groups that are difficult to access, such as those that are spread over a large area, like the settlement of São Diogo.

In this study, the settlers will be treated as managers when referring to the agroforestry homegardens. In each household, the manager was first contacted with the goal of demonstrating the importance of the proposed research. After accepting to participate in the survey, the data was collected by a guided tour technique, in which the manager walked us through his/her homegarden and provided the requested information for this study (ALBUQUERQUE; LUCENA, 2008), such as number of people in the household, management practices, and production purposes. 
A census was taken of individuals from the tree and shrub strata in order to evaluate the floristic composition of each homegarden. The identification of ethno species was carried out following Semedo and Barbosa (2007), Linhares et al., (2014), and Rayol, Vale, and Miranda (2017). Briefly, the names of the ethno species were recorded according to the manager and previous knowledge of the authors. In case of uncertainty, the identification was done through literature review.

The Shannon-Wiener index was used to characterize the species diversity in each homegarden and was calculated according to the following equation:

$$
-\sum_{i=1}^{S} p_{i} \ln p_{i}
$$

where $\mathrm{H}^{\prime}$ is the diversity index, $\mathrm{pi}$ is the ratio between the number of individuals of the species (ni), and the total number of individuals observations $(\mathrm{N})$, for i ranging from 1 to $S$ (Richness).

The usage pattern of the main species was analyzed using the preference index (IVP\%), calculated by the sum of abundance (Abu\%) and relative frequency (Fre\%) (SEMEDO; BARBOSA, 2007). Pearson's linear correlation analysis was conducted using the following variables: age of homegarden, species richness, abundance, and $\mathrm{H}^{\prime}$. Descriptive statistical analysis was carried out using Excel for Windows In order to assess similarity among groups of agroforestry homegardens, data were submitted to cluster analysis using the Ward method and Euclidean Distance through the BioEstat Software, version 5.3.

\section{RESULTS AND DISCUSSION}

A total of 32 species were found across homegardens, comprising of 26 genera and 18 botanical families that were all fruit bearing. Of these, $85.7 \%$ of the species were used for self-consumption, and $14.3 \%$ for both self-consumption and 
commercialization (Table 1). These results highlight the role of homegardens in providing food for self-consumption in family farm areas. Similar results were reported by Almeida and Gama (2014), in which the authors observed a predominance of plant species intended for self-consumption in a settlement project located western Pará.

Table 1 - Plant species of trees and shrubs strata in agroforestry homegardens in the Agro-extractive Settlement Project of São Diogo, Monte Alegre, Pará, Brazil (N = 37).

\begin{tabular}{|c|c|c|c|c|c|c|c|c|}
\hline Family & $\begin{array}{c}\text { Scientific } \\
\text { name }\end{array}$ & $\begin{array}{l}\text { Ethno } \\
\text { specie }\end{array}$ & Fre\% & Abu\% & PI\% & Purpose & Management & Production \\
\hline \multirow[t]{2}{*}{ Anacardiaceae } & $\begin{array}{l}\text { Anacardium } \\
\text { occidentale L. }\end{array}$ & Cashew & 21.6 & 1.5 & 23.1 & $S$ & $F, I, W, P$ & $S, W$ \\
\hline & $\begin{array}{c}\text { Mangifera indica } \\
\text { L. }\end{array}$ & Mango & 73 & 3.7 & 76.7 & $S$ & $\mathrm{~F}, \mathrm{I}, \mathrm{W}, \mathrm{P}$ & $S, W$ \\
\hline \multirow[t]{3}{*}{ Annonaceae } & $\begin{array}{c}\text { Annona } \\
\text { squamosa } \mathrm{L} .\end{array}$ & $\begin{array}{l}\text { Sugar } \\
\text { apple }\end{array}$ & 16.2 & 1.2 & 17.4 & $S$ & $\mathrm{~F}, \mathrm{I}, \mathrm{W}$ & $S, W$ \\
\hline & $\begin{array}{c}\text { Rollinia deliciosa } \\
\text { Saff. }\end{array}$ & Biribá & 2.7 & 0.1 & 2.8 & $S$ & W & $S, W$ \\
\hline & $\begin{array}{c}\text { Annona } \\
\text { muricata L. }\end{array}$ & Soursop & 18.9 & 1.0 & 19.9 & $S$ & $\mathrm{~F}, \mathrm{I}, \mathrm{W}, \mathrm{P}$ & W \\
\hline Apocynaceae & $\begin{array}{l}\text { Hancornia } \\
\text { speciosa } \\
\text { Gomes }\end{array}$ & Mangaba & 2.7 & 0.1 & 2.8 & $S$ & $\mathrm{~F}, \mathrm{~W}$ & $S$ \\
\hline \multirow[t]{5}{*}{ Arecaceae } & $\begin{array}{c}\text { Euterpe oleracea } \\
\text { Mart. }\end{array}$ & Açaí & 75.7 & 29 & 104.7 & $S / C$ & $\mathrm{~F}, \mathrm{I}, \mathrm{W}, \mathrm{P}$ & $S, W$ \\
\hline & $\begin{array}{c}\text { Oenocarpus } \\
\text { bacaba Mart. }\end{array}$ & Bacaba & 2.7 & 0.1 & 2.8 & $S$ & $P$ & W \\
\hline & $\begin{array}{c}\text { Cocos nucifera } \\
\text { L. }\end{array}$ & Coconut & 89.2 & 6.4 & 95.6 & $S$ & $\mathrm{~F}, \mathrm{I}, \mathrm{W}, \mathrm{P}$ & $S, W$ \\
\hline & $\begin{array}{c}\text { Acrocomia } \\
\text { aculeata } \\
\text { (Jacq.) Lodd. ex } \\
\text { Mart. }\end{array}$ & $\begin{array}{l}\text { Macaw } \\
\text { palm }\end{array}$ & 2.7 & 0.1 & 2.8 & $S$ & I & W \\
\hline & $\begin{array}{l}\text { Bactris gasipaes } \\
\text { Kunth }\end{array}$ & Peach palm & 18.9 & 0.7 & 19.6 & $S$ & $\mathrm{~F}, \mathrm{I}, \mathrm{W}$ & $\mathrm{S}, \mathrm{W}$ \\
\hline Bignoniaceae & $\begin{array}{c}\text { Crescentia cujete } \\
\text { L. }\end{array}$ & $\begin{array}{c}\text { Calabash } \\
\text { tree }\end{array}$ & 5.4 & 0.3 & 5.7 & $S$ & $W, P$ & $S, W$ \\
\hline Caricaceae & Carica papaya L. & Papaya & 2.7 & 0.6 & 3.3 & $S$ & $W, P$ & $S, W$ \\
\hline Clusiaceae & $\begin{array}{c}\text { Platonia insignis } \\
\text { Mart. }\end{array}$ & Bacuri & 2.7 & 0.1 & 2.8 & $S$ & W & $\mathrm{S}, \mathrm{W}$ \\
\hline Fabaceae & $\begin{array}{l}\text { Inga edulis } \\
\text { Mart. }\end{array}$ & $\begin{array}{l}\text { Ice-cream- } \\
\text { bean }\end{array}$ & 24.3 & 0.7 & 25 & $S$ & $\mathrm{~F}, \mathrm{I}, \mathrm{W}, \mathrm{P}$ & $\mathrm{S}, \mathrm{W}$ \\
\hline Lauraceae & $\begin{array}{c}\text { Persea } \\
\text { americana Mill. }\end{array}$ & Avocado & 24.3 & 1.2 & 25.5 & $S$ & $\mathrm{~F}, \mathrm{I}, \mathrm{W}, \mathrm{P}$ & $S, W$ \\
\hline
\end{tabular}




\begin{tabular}{|c|c|c|c|c|c|c|c|c|}
\hline Family & $\begin{array}{l}\text { Scientific } \\
\text { name }\end{array}$ & $\begin{array}{l}\text { Ethno } \\
\text { specie }\end{array}$ & Fre\% & Abu\% & $\mathrm{PI} \%$ & Purpose & Management & Production \\
\hline \multirow[t]{2}{*}{ Malpighiaceae } & $\begin{array}{c}\text { Malpighia } \\
\text { punicifolia L. }\end{array}$ & $\begin{array}{l}\text { Native } \\
\text { cherry }\end{array}$ & 21.6 & 2 & 23.6 & $S$ & $\mathrm{~F}, \mathrm{I}, \mathrm{W}$ & $S, W$ \\
\hline & $\begin{array}{l}\text { Byrsonima } \\
\text { crassifolia } \\
\text { (L.) Kunth }\end{array}$ & Nanche & 62.2 & 6.8 & 69 & $\mathrm{~S} / \mathrm{C}$ & $\mathrm{F}, \mathrm{I}, \mathrm{W}, \mathrm{P}$ & $S, W$ \\
\hline \multirow[t]{2}{*}{ Malvaceae } & $\begin{array}{c}\text { Theobroma } \\
\text { cacao L. }\end{array}$ & Cacao & 8.1 & 6.2 & 14.3 & $S$ & $\mathrm{I}, \mathrm{W}$ & $S, W$ \\
\hline & $\begin{array}{l}\text { Theobroma } \\
\text { grandiflorum } \\
\text { (Willd. ex } \\
\text { Spreng.) K. } \\
\text { Schum. }\end{array}$ & Cupuassu & 29.7 & 2.2 & 32 & $S$ & $\mathrm{~F}, \mathrm{I}, \mathrm{W}, \mathrm{P}$ & $S, W$ \\
\hline Metteniusaceae & $\begin{array}{l}\text { Poraqueiba } \\
\text { paraensis } \\
\text { Ducke } \\
\end{array}$ & Marí & 10.8 & 0.3 & 11.1 & $S$ & $\mathrm{I}, \mathrm{W}, \mathrm{P}$ & $S, W$ \\
\hline Moraceae & $\begin{array}{c}\text { Artocarpus } \\
\text { heterophyllus } \\
\text { Lam. }\end{array}$ & Jackfriut & 8.1 & 0.4 & 8.5 & $S$ & $W, P$ & W \\
\hline Musaceae & Musa spp. & Banana & 56.8 & 12.5 & 69.2 & $S$ & $\mathrm{~F}, \mathrm{I}, \mathrm{W}, \mathrm{P}$ & $\mathrm{S}, \mathrm{W}$ \\
\hline \multirow[t]{3}{*}{ Myrtaceae } & $\begin{array}{c}\text { Syzygium } \\
\text { cuminis } \\
\text { (Craib) Chantar. } \\
\text { \&J. Parn. }\end{array}$ & Olive & 2.7 & 0.1 & 2.8 & $S$ & $F, P$ & $S$ \\
\hline & $\begin{array}{c}\text { Psidium guajava } \\
\text { L. } \\
\end{array}$ & Guava & 40.5 & 2.7 & 43.2 & $S$ & $\mathrm{~F}, \mathrm{I}, \mathrm{W}, \mathrm{P}$ & $\mathrm{S}, \mathrm{W}$ \\
\hline & $\begin{array}{l}\text { Syzygium } \\
\text { jambos } \\
\text { (L.) Alston }\end{array}$ & Rose-apple & 21.6 & 0.8 & 22.4 & $S$ & $\mathrm{~F}, \mathrm{I}, \mathrm{W}, \mathrm{P}$ & $S, W$ \\
\hline Oxalidaceae & $\begin{array}{c}\text { Averrhoa } \\
\text { carambola L. }\end{array}$ & Star fruit & 2.7 & 0.1 & 2.8 & $S$ & $\mathrm{~F}, \mathrm{I}, \mathrm{W}$ & $\mathrm{S}, \mathrm{W}$ \\
\hline \multirow[t]{4}{*}{ Rutaceae } & $\begin{array}{l}\text { Citrus sinensis } \\
\text { (L.) Osbeck }\end{array}$ & Orange & 56.8 & 1.1 & 57.8 & $S$ & $F, I, W, P$ & $\mathrm{~S}, \mathrm{~W}$ \\
\hline & $\begin{array}{l}\text { Citrus limon } \\
\text { (L.) Osbeck }\end{array}$ & Lemon & 73 & 8.1 & 81 & $S / C$ & $\mathrm{~F}, \mathrm{I}, \mathrm{W}, \mathrm{P}$ & $\mathrm{S}, \mathrm{W}$ \\
\hline & $\begin{array}{l}\text { Citrus } \\
\text { aurantifolia } \\
\text { Swingle } \\
\end{array}$ & Key lime & 5.4 & 0.8 & 6.2 & $S / C$ & 1 & $S, W$ \\
\hline & $\begin{array}{c}\text { Citrus reticulata } \\
\text { Blanco }\end{array}$ & Mandarin & 18.9 & 0.7 & 19.6 & $S$ & $\mathrm{~F}, \mathrm{I}, \mathrm{W}$ & $S, W$ \\
\hline Zapotaceae & $\begin{array}{c}\text { Manilkara } \\
\text { zapota (L.) P. } \\
\text { Royen } \\
\end{array}$ & Sapodilla & 2.7 & 0.6 & 3.3 & $S$ & $\mathrm{~F}, \mathrm{~W}$ & W \\
\hline
\end{tabular}

Fre $\%$ = relative frequency; $\mathrm{Abu} \%=$ abundance; IVP\% = preference index

Purpose: $S=$ self-consumption; $C=$ commercialization

Management: $\mathrm{W}=$ weeding; $\mathrm{F}=$ fertilizer; $\mathrm{I}=$ irrigation; $\mathrm{P}=$ pesticide

Production: $\mathrm{S}=$ summer; $\mathrm{W}=$ winter 
The most frequent species were Cocos nucifera with a relative frequency of $89.2 \%$, followed by Euterpe oleracea (75.7\%), Mangifera indica (73\%), and Citrus limon (73\%). In addition to Euterpe oleracea, which is a native species to the Amazon, the other most frequent species adapt well to the Amazonian climate. In a rural community in Santarém (State of Pará), Rocha-Garcia, Vieira and Oliveira (2015) showed that coconut was the most consumed fruit in agroforestry homegardens. Similarly, Silva et al., (2017) reported that coconut was found in at least $50 \%$ of the homegardens surveyed in a rural community in the city of Bragança (State of Pará). Coconut was also found to be the most frequent species ( $78 \%$ relative frequency) in urban homegardens managed by indigenous people in the city of São Gabriel da Cachoeira (State of Amazonas) (PINTO, 2012). According to Vieira, Rosa and Santos (2012), the high frequency of Cocos nucifera is attributed to socioeconomic and cultural issues, as the seedlings are produced and acquired by neighbors.

Coconut is a palm tree that is grown for multiple purposes as most parts of the plant are used daily, especially those with nutritional and medicinal values. The coconut water, oil, leaves, bark, fiber, and stipe-based products are emphasized for these purposes (MANDAL; MANDAL, 2011).

The high frequency of fruit species in homegardens was also observed by Vieira, Rosa and Santos (2012) and Rayol and Miranda (2019), who demonstrated that this choice was primarily intended to ensure food supply to the household of the farmers in the Amazon region. In addition, Pereira et al. (2010) argued that fruit species also contribute to the permanence of the farmers in the rural areas.

Another species that is present at high frequency in the homegardens was the Euterpe oleracea, which showed the greatest importance in this study. This species is used for both self-consumption and commercialization. Its preference, in addition to cultural issues, is likely related to the high nutritional and economic value of the açaí fruit. This fact was also reported by Vieira, Rosa and Santos (2012), showing that the juice of the açaí fruit, also called "açaí wine", was quite valued 
throughout the Amazon region and was also present in the eating habits of households in the city of Bonito, State of Pará.

It must be highlighted that the surplus production is commonly used for commercialization by family farms. Duval, Ferrante and Valêncio (2008) and Almeida and Gama (2014) highlighted that the agricultural production represents an alternative source of income and social inclusion for the settlers.

Mangifera indica, commonly known as mango, was found in $73 \%$ of the homegardens in this study. This exotic species is of great importance, since its fruit production occurs at different times of the year, thereby complementing the household diet. The high frequency of Mangifera indica was also observed by Almeida and Gama (2014), which reported an $83.3 \%$ relative frequency in homegardens in the rural community of Santo Antônio, a settlement project located in Santarém, Pará. The authors also reported that this species was used primarily for self-consumption, since there is no demand for sales within the community.

The lemon (Citrus limon) was another species that presented high frequency and socioeconomic importance within the agroforestry homegardens. Our data showed that the lemon fruits were not only used for self-consumption but also for commercialization, thereby generating revenue to the farmers. Lunz (2007) also reported high frequency of lemon (80\%) within homegardens in a cooperative of small farmers in the State of Rondônia. Similarly, Almeida and Gama (2014) also demonstrated the importance of this species within homegardens in the rural community of Santo Antônio (State of Para).

The study of floristic compositions of homegardens, along with species structure and properties, can provide basic information to assist with decision making, leading to greater adoption of improved management and conservation practices in the region (GAZEL FILHO, 2008). In this study, the Shannon-Weaver index showed that species diversity varied from 0.6 to 2.46 with a mean value of 1.55 , which is considered moderate in the literature (Table 2). 
Table 2 - Species diversity calculated by the Shannon index ( $\mathrm{H}^{\prime}$ ) and size (in m3) of each agroforestry homegarden (AFH) in the rural community of São Diogo, Monte Alegre, Pará

\begin{tabular}{lcccccccc}
\hline $\mathbf{A F H}$ & $\mathbf{H}^{\prime}$ & Size & AFH & $\mathbf{H}^{\prime}$ & Size & AFH & $\mathbf{H}^{\prime}$ & Size \\
\hline $\mathbf{1}$ & 0.60 & 120 & $\mathbf{1 4}$ & 2.08 & 11,250 & $\mathbf{2 7}$ & 1.28 & 460 \\
$\mathbf{2}$ & 0.95 & 5,200 & $\mathbf{1 5}$ & 1.45 & 1,880 & $\mathbf{2 8}$ & 1.11 & 1,000 \\
$\mathbf{3}$ & 2.13 & 10,000 & $\mathbf{1 6}$ & 1.60 & 2,450 & $\mathbf{2 9}$ & 1.40 & 800 \\
$\mathbf{4}$ & 0.65 & 6,400 & $\mathbf{1 7}$ & 1.92 & 2,679 & $\mathbf{3 0}$ & 1.38 & 3,040 \\
$\mathbf{5}$ & 2.18 & 300 & $\mathbf{1 8}$ & 1.21 & 750 & $\mathbf{3 1}$ & 2.33 & 2,400 \\
$\mathbf{6}$ & 1.81 & 450 & $\mathbf{1 9}$ & 2.05 & 500 & $\mathbf{3 2}$ & 1.90 & 7,200 \\
$\mathbf{7}$ & 1.64 & 200 & $\mathbf{2 0}$ & 2.29 & 1,600 & $\mathbf{3 3}$ & 2.25 & 900 \\
$\mathbf{8}$ & 2.08 & 2,100 & $\mathbf{2 1}$ & 2.16 & 3,000 & $\mathbf{3 4}$ & 1.83 & 2,160 \\
$\mathbf{9}$ & 0.77 & 450 & $\mathbf{2 2}$ & 1.74 & 300 & $\mathbf{3 5}$ & 2.13 & 750 \\
$\mathbf{1 0}$ & 1.21 & 200 & $\mathbf{2 3}$ & 1.64 & 1,000 & $\mathbf{3 6}$ & 1.47 & 2,700 \\
$\mathbf{1 1}$ & 2.27 & 2,500 & $\mathbf{2 4}$ & 2.46 & 1,250 & $\mathbf{3 7}$ & 1.68 & 1,125 \\
$\mathbf{1 2}$ & 2.13 & 450 & $\mathbf{2 5}$ & 0.86 & 450 & Mean & 1.55 & 1,673 \\
$\mathbf{1 3}$ & 1.68 & 600 & $\mathbf{2 6}$ & 1.38 & 480 & Std. Dev. & 0.63 & 2,521 \\
\hline
\end{tabular}

Std. Dev. $=$ standard deviation

The statistical analysis showed low correlation between size of the homegarden and abundance (34.3\%), and between age of homegarden and its species richness $(29.1 \%)$, indicating low predictive power among variables. In agroforestry homegardens in Caruaru city (State of Pernambuco), Florentino, Araújo, and Albuquerque (2007) also found low correlation among these variables. In contrast, Vieira, Rosa and Santos (2012) found positive and moderate correlation between size and species richness of homegardens, in which larger homegarden size presented greater species richness. In this sense, extension educators could assist managers with the implementation of practices that aim to increase species abundance in their homegarden, especially those with large areas.

The species diversity of homegardens in a rural community in Santarém was also found to be moderate, whereas species richness was considered average with high frequency of certain species, such as banana and açaí (GARCIA; VIEIRA; OLIVEIRA, 2017). These authors also reported that the origin of the farmers can influence the species richness, density, and diversity, as there were higher values in homegardens managed by migrant farmers from southern Brazil. 
The average age of the homegardens assessed in this study was 12 years-old. The average size was $2,138 \mathrm{~m} 3$, ranging from 120 to $11,250 \mathrm{m3}$. It is important to highlight that the rural community is part of a settlement where the lots are collective, which likely resulted in the wide variation in size. However, the mean size of homegardens found in this study was similar to those reported by Melo et al. (2018) in the metropolitan region of Santarém, and approximately 1.3-fold larger than those reported by Vieira, Rosa and Santos (2012) in a rural community located northeastern Pará.

The cluster analysis showed the homegardens were divided into three groups (Figure 2). Group A ( $=7$ ) was represented by homegardens with an average species diversity of 1.52 , average size of $6,081 \mathrm{~m} 3$, and approximately 120 individuals per garden. Group $B(N=12)$ was characterized by an average species diversity of 2.15, mean area of 1,515.75 m3, and 53 individuals per homegarden. On the other hand, group $C(\mathrm{~N}=18)$ were the homegardens with a mean diversity index of 1.41, approximately $1,018 \mathrm{~m} 3$ area, and 27 individuals per garden.

Figure 2 - Dendogram showing the hierarchical relationship between agroforestry homegardens in the rural community of São Diogo, Monte Alegre, Pará

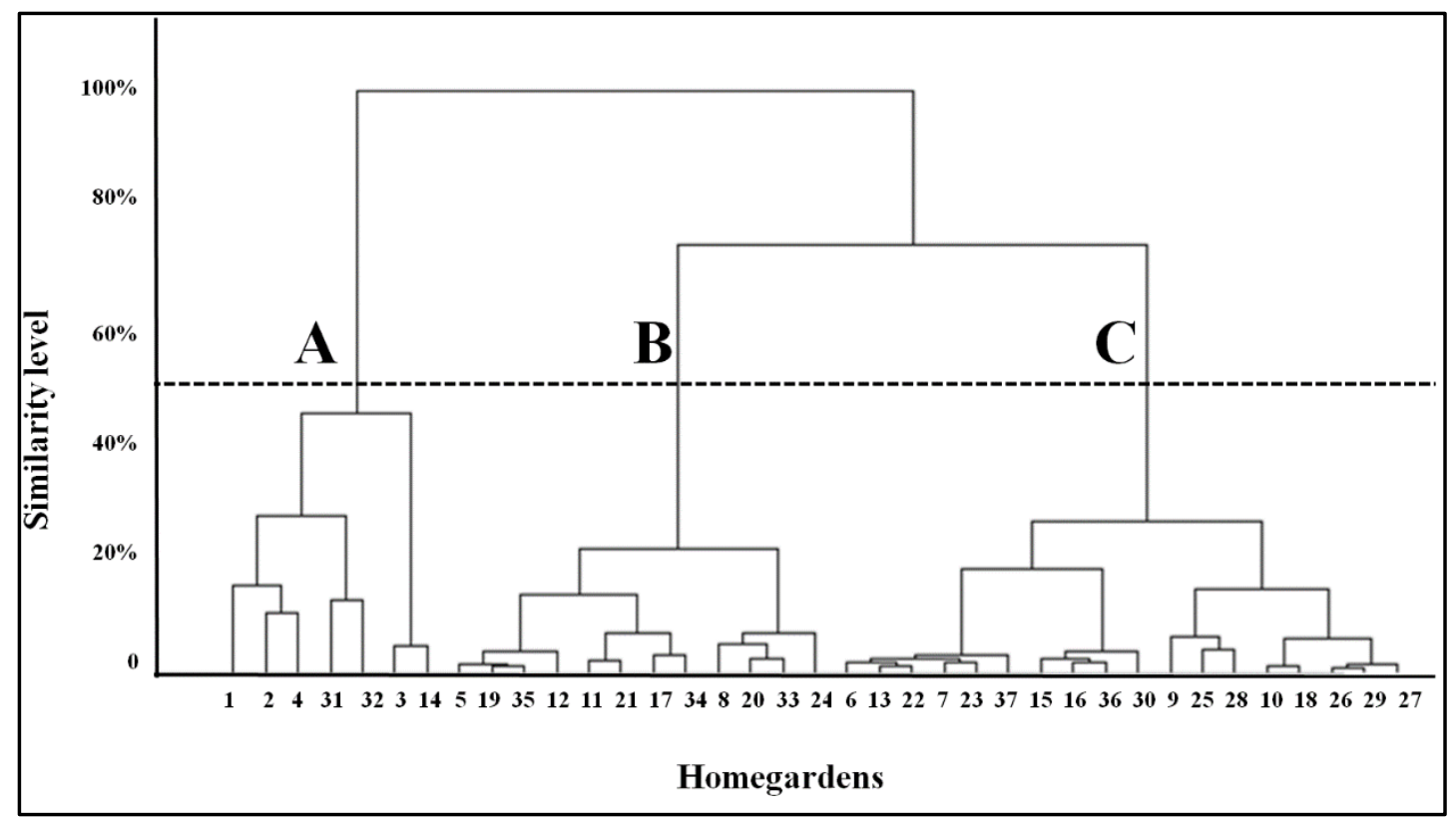


There was a predominance of small homegardens with low number of individuals in group $C$, which could have resulted in moderate to low species diversity. However, they still are important production areas that supply food to the settled families. Self-consumption was the main reason (87.5\%) for the cultivation of species in the trees and shrubs strata evaluated in this study. The present analysis also showed that none of the plant species grown were exclusively for commercialization purposes.

The plant species were grown by the settlement farmers were for selfconsumption but presented possibility for commercialization. According to Menasche, Marques and Zanetti (2008), agricultural production for self-consumption is a way of promoting food security for family farms in this region. In a settlement project in São Domingos do Araguaia (State of Para), Pereira et al. (2010) highlighted that the commercialization of surplus production is an important addition to the farmer income. However, the lack of demand in the community and the difficulty in transportation are key factors that hinder the commercialization of the products, which helps to explain why production for self-consumption is more evident.

During the guided tour, the managers reported several management practices, including manual weeding, irrigation, fertilization, and pesticide application. There is a predominance of the use of family labor with simple management techniques instead of farming machinery. Florentino, Araújo and Albuquerque (2007) reported similar results regarding the use of family labor without machinery that represent management practices involving simple and low cost techniques.

The manual weeding, usually with a garden hoe, consists of removing invasive plants. This is an effective way of controlling weeds in the region, which were found in $24.3 \%$ of the homegardens. Despite the fact that manual weeding is not the most economical way of controlling weeds, it is still of great importance in several regions of Brazil (GOMES; LEAL, 2003).

Irrigation complements the water demand by plants during the dry season and, thus, helps maintain crop production. Because the studied community is 
located near the river, the water was not a limited resource. Thus, managers can invest in technologies for water storage and irrigation equipment. The present results showed that irrigation was a common management practice in $37.8 \%$ of the homegardens surveyed. Irrigation is an artificial method of applying water in agricultural lands, and the main goal is to partially complement water demand by plants, using water resources present in the area (SOUSA, 2018).

In a study evaluating homegardens in the city of Cáceres (State of Mato Grosso), Pereira and Figueiredo-Neto (2015) reported similar management practices to those found in this study, emphasizing such practices during the dry season when plant demands for water and nutrients are high.

The establishment of these agroforestry systems near the manager households can provide better access to high-quality food, especially with regard to the consumption of the fruits produced in these areas. In addition, commercialization of the surplus production can benefit the household with extra income.

\section{CONCLUSION}

The floristic composition of agroforestry homegardens was represented by species for which the production primarily serves for household consumption. The observed results emphasize açaí and coconut palms, which corresponded to the two highest importance indices.

Overall, the homegardens showed moderate species diversity for trees and shrubs strata evaluated in this study. Based on the similarity among homegardens, they were divided into three groups, in which the size and number of plants of each homegarden influenced the diversity index within the clusters.

Across homegardens, the managers reported several management practices, including the use of simple technologies, no machinery, and irrigation during the dry season when plant demands for water and nutrients are high. 
The production within homegardens can contribute to the revenue and the food security of the settlement families, which in turn justifies the establishment of agroextractive settlements.

The results of the floristic composition of homegardens reported here will be of major importance to help settlers to adopt management techniques to increase productivity while conserving the agrobiodiversity in this area.

\section{ACKNOWLEDGEMENTS}

We would also like to thank Michael James Stablein of the University of Illinois Urbana-Champaign for his translation services and review of this work.

\section{REFERENCES}

ABREU, M. C.; SILVA, P. H.; OLIVEIRA, Y. R. Vegetais cultivados em quintais rurais Piauienses com indicação anticâncer: uma busca pelo conhecimento tradicional. Ciência e Natura, v. 39, n. 1, p. 22-32, 2017.

ALBUQUERQUE, U. P.; LUCENA, R. F. P. Métodos e técnicas na pesquisa etnobotânica. 2 ed. Recife: NUPEEA, 2008.

ALMEIDA, L. S.; GAMA, J. R. V. Quintais agroflorestais: estrutura, composição florística e aspectos socioambientais em área de assentamento rural na Amazônia brasileira. Ciência Florestal, v. 24, n. 4, p. 1041-1053, 2014.

DAMACENO, J. B. D.; LOBATO, A. C. N. Caracterização de um quintal agroflorestal na Amazônia Central, Brasil. Revista Brasileira de Gestão Ambiental e Sustentabilidade, v. 6, n. 12, p. 163173, 2019.

DAS, T.; DAS, A. K. Agrobiodiversity in Northeast India: A Review of the Prospects of Agrobiodiversity Management in the Traditional Rice Fields and Homegardens of the Region. In: ROY, N.; ROYCHOUDHURY, S.; NAUTIYAL, S.; AGARWAL, S.; BAKSI, S. (eds) Socio-economic and Eco-biological Dimensions in Resource use and Conservation. Environmental Science and Engineering. Springer, Cham, 2020.

DUVAL, H. C.; FERRANTE, V. B.; VALÊNCIO, N. F. L. S. Produção de autoconsumo em assentamentos rurais: princípios da agricultura sustentável e desenvolvimento. In: Congresso 
da Sociedade Brasileira de Economia, Administração e Sociologia Rural, 46. Anais... 2008 jul 2023. Rio Branco, Brasil.

FLORENTINO, A. T. N.; ARAÚJO, E. L.; ALBUQUERQUE, U. P. Contribuição de quintais agroflorestais na conservação de plantas da Caatinga, município de Caruaru, PE, Brasil. Acta Botânica Brasilica, v. 21, n. 1, p. 37-47, 2007.

GARCIA, B. N. R.; VIEIRA, T. A.; OLIVEIRA, F. A. Tree and shrub diversity in agroforestry homegardens in rural community in eastern Amazon. Revista Floresta, v. 47, n. 4, p. 543-552, 2017.

GAZEL FILHO, A. B. Composição, estrutura e função de quintais agroflorestais no Município de Mazagão, Amapá. 2008. 104f. Tese (Doutorado em Ciências Agrárias) Universidade Federal Rural da Amazônia; Embrapa Amazônia Oriental, Belém, 2008.

GEORGE, M. V.; CHRISTOPHER, G. Structure, diversity and utilization of plant species in tribal homegardens of Kerala, India. Agroforestry Systems, v. 94, p. 297-307, 2020.

GOMES, J. A.; LEAL, E. C. Cultivo da Mandioca para a Região dos Tabuleiros Costeiros. Brasília: Embrapa, 2003. (Sistemas de produção. 11).

LINHARES, J. F. P.; HORTEGAL, E. V.; RODRIGUES, M. I. A.; SILVA, P. S. S. Etnobotânica das principais plantas medicinais comercializadas em feiras e mercados de São Luís, Estado do Maranhão, Brasil. Rev Pan-Amaz Saude, v. 5, n. 3, p. 39-46, 2014.

LUNZ, A. M. P. Quintais agroflorestais e o cultivo de espécies frutíferas na Amazônia. Revista Brasileira de Agroecologia, v. 2, n. 2, 2007.

MACENA, L.; VILA, N. Etnobotânica e a adoção de práticas agroecológicas segundo a percepção dos assentados do Assentamento Palmares. Biodiversidade, v. 19, n. 1, p. 50-66, 2020.

MANDAL, M. D.; MANDAL, S. Coconut (Cocos nucifera L.: Arecaceae): in health promotion and disease prevention. Asian Pacific Journal of Tropical Medicine, v. 4, n. 3, p. 241-247, 2011.

MELO, M. B.; ALMEIDA, B. R. S.; BATISTA, A. S.; PAULETTO, D.; BALONEQUE, D. D. Composição florística e fitossociologia de quintais agroflorestais na zona urbana no Oeste do Pará. Cadernos de Agroecologia, v. 13, n. 1, 2018.

MENASCHE, R.; MARQUES, F. C.; ZANETTI, C. Autoconsumo e segurança alimentar: a agricultura familiar a partir dos saberes e práticas da alimentação. Revista de Nutrição, v. 21, p. 145-158, 2008.

MICCOLIS, A.; PENEIREIRO, F. M.; MARQUES, H. R.; VIEIRA, D. L. M.; ARCO-VERDE, M. F.; HOFFMANN, M. R.; REHDER, T.; PEREIRA, A. V. B. Restauração ecológica com Sistemas Agroflorestais: como conciliar conservação com produção - opções para Cerrado e Caatinga. Brasília: ISPN; ICRAF, 2016. 266p. 
MIDMORE, D. J. Principles of tropical horticulture. Oxfordshire: CABI, 2015. 438p.

OLIVEIRA, M. S. L.; SILVA, L. M. S. Impactos do PRONAF na sustentabilidade de agroecossistemas familiares da comunidade quilombola Nova Betel, Tomé Açu - Pará. Agricultura Familiar: Pesquisa, Formação e Desenvolvimento, v. 13, n. 2, p. 57-80, 2019.

PEREIRA, P. V. M.; FIGUEIREDO NETO, L. F. Conservação de espécies florestais: um estudo em quintais agroflorestais no município de Cáceres - MT. REGET, v. 9, n. 3, p. 783-793, 2015.

PEREIRA, C. N.; MANESCHY, R. Q.; OLIVEIRA, P. D.; OLIVEIRA, I. K. S. Caracterização de quintais agroflorestais no Projeto de Assentamento Belo Horizonte I, São Domingos do Araguaia, Pará. Agroecossistemas, v. 2, n.1, p. 73-81, 2010.

PINTO, E. P. P.; SOUZA, M. L. L.; CARDOSO, A. M.; CARVALHO, E. S.; NASCIMENTO, D. R.; MOUTINHO, P. R. S.; MARQUES, C. B.; PIONTEKOWSKI, V. J. Assentamentos Sustentáveis na Amazônia: o desafio da produção familiar em uma economia de baixo carbono. In: GRAMKOW, C. (org.). Investimentos transformadores para um estilo de desenvolvimento sustentável: Estudos de casos de grande impulso (Big Push) para a sustentabilidade no Brasil. Santiago: Nações Unidas, 2020. p. 89-102.

PINTO, I. C. Agrobiodiversidade de quintais agroflorestais urbanos e perfil social de etnias indígenas em São Gabriel, AM. 2012. 196f. Tese (Doutorado em Ciências Florestais) Universidade Federal de Lavras, Lavras, 2012.

SEMEDO, R. J. C. G.; BARBOSA, R. I. Árvores frutíferas nos quintais urbanos de Boa Vista, Roraima, Amazônia brasileira. Acta Amazonica, v. 37, n. 4, p. 497-504, 2007.

SILVA, H. K. M.; GAMA, J. R. V.; SOUSA, R. J. A.; LAMEIRA, M. K. S.; COSTA, D. L.; OLIVEIRA, D. V.; ROCHA, J. S.; OLIVEIRA, T. G. S. Composição florística de quintais agroflorestais na Vila Cuera, Bragança, Pará. Agroecossistemas, v. 9, n. 2, p. 330-338, 2017.

RAYOL, B. P.; MIRANDA, I. S. Quintais agroflorestais na Amazônia Central: caracterização, importância social e agrobiodiversidade. Ciência Florestal, v. 29, n. 4, p. 1614-1629, 2019.

RAYOL, B.P.; VALE, I.; MIRANDA, I. S. Tree and palm diversity in homegardens in the Central Amazon. Agroforestry systems, v. 93, n. 2, p. 515-529, 2017.

SOUSA, P. F. C. Irrigação e Drenagem. Londrina: Editora e Distribuidora Educacional, 2018.

ROCHA-GARCIA, B.N.; VIEIRA, T. A.; OLIVEIRA, F. S. Quintais agroflorestais e segurança alimentar em uma comunidade rural na Amazônia Oriental. Revista de la Facultad de Agronomía, v. 114 , p. 67-73, 2015.

ROMUALDO, P. L.; DELIBERALI, D. C.; JUCKSCH, I. CARDOSO, I. M. Pesquisa solidária e participativa em assentamento de reforma agrária: as potencialidades e desafios na construção da agroecologia, no manejo do rebanho leiteiro, das pastagens e do solo. In: CARMO, D. L.; 
PEREIRA, D. S.; MIGUEL, E. S.; LOPES, S. O.; PRIORE, S. E. (Eds.) Pesquisa em Agroecologia: conquistas e perspectivas. Viçosa: Funarbe, 2019. p. 211-233.

VIEIRA, T. A.; ROSA, L. S.; SANTOS, M. M. L. S.; SANTOS, C. A. A.; LUSTOSA, D. C.; SANTOS, A. P. A. Chemical properties of soils in agroforestry homegardens and other land use systems in Eastern Amazon, Brazil. African Journal of Agricultural Research, v. 11, n. 29, p. 2616-2611, 2016.

VIEIRA, T. A.; ROSA, L. S.; SANTOS, M. M. L. S. Wellbeing of smallholders maintaining homegardens: a case study of rural communities in the Eastern Amazon. Tropical and Subtropical Agroecosystems, v. 18, n. 1, p. 1-10, 2015.

VIEIRA, T. A.; ROSA, L. S.; SANTOS, M. M. L. S. Agrobiodiversidade de quintais agroflorestais no município de Bonito, Estado do Pará. Revista de Ciências Agrárias, v. 55, n. 3, p. 159-166, 2012.

VINUTO, J. A. Amostragem em bola de neve na pesquisa qualitativa: um debate em aberto. Temáticas, v. 22, n. 44, p. 203-220, 2014.

\section{Authorship contributions}

\section{1 - Deiwisson Willam da Silva Santos}

Engenheiro Florestal, Mestrando pelo Programa de Pós-Graduação em Engenharia Florestal http://orcid.org/0000-0001-7760-4353 - deiwissondws2@gmail.com

\section{2 - Thiago Almeida Vieira}

Doutor em Ciências Agrárias, Professor na Universidade Federal do Oeste do Pará http://orcid.org/0000-0001-9926-2606 - thiago.vieira@ufopa.edu.br 